\title{
Læring av yrkesetikk - nytter utdanning? En forskningsbasert fremstilling
}

\author{
Tone Dyrdal Solbrekke
}

Denne artikkelen innledes med en forutsetning: at dagens samfunn er sterkt avhengig av ekspertsystemer som utvikles og forvaltes av profesjoner og deres medlemmer. Profesjonsutøvelse må derfor forankres i faglig kunnskap og ikke minst i en reflektert etisk bevissthet om profesjoners samfunnsoppdrag. Med dette som utgangspunkt påpekes det $i$ denne artikkelen at høyere utdanning har ansvar for å utdanne kommende profesjonsutøvere med moralsk handlingsberedskap. I lys av dette gjennomgås nasjonal og internasjonal forskning på loering av yrkesetikk innenfor ulike profesjonsutdanninger og erfaringer med yrkesetikk i praksis. Funn fra disse studiene viser at mange nyutdannede ikke opplever å vore godt nok forberedt på yrkesetiske dilemmaer. Det indikerer at høyere utdanning ikke jobber med loering av yrkesetikk på en tilstrekkelig måte. Andre funn viser at i profesjonsutdanninger der det har voert jobbet systematisk med moralske spørsmål relatert til autentiske case, synes studenter å utvikle en mer bevisst yrkesetisk handlingsberedskap. Det konkluderes med at empirisk forskning bidrar med verdifull kunnskap om sentrale og kritiske forutsetninger og faktorer vi må ta hensyn til om målet er å danne grunnlag for en reflektert yrkesetisk handlingskompetanse for et konfliktfylt arbeidsliv. Systematisk utdanning i moralsk resonnement, deltagelse i praksis, utvikling av et etisk språk og en bevissthet om profesjonsmoralens forankring, er sentralt. Vi trenger imidlertid mer empirisk forskning på forholdet mellom det normative mandat og den enkelte profesjonsutøvers forståelse av yrkesetikk og handling i praksis. Det vil kunne øke vår innsikt $i$ hvordan høyere utdanning kan hjelpe fremtidige profesjonsutøvere til moralsk handlingsberedskap.

Nøkkelord: profesjonsmandat, yrkesetikk, læring, reflektert handlingsberedskap 


\section{Innledning ${ }^{1}$}

Dagens komplekse samfunn hviler i stor grad på at vi kan ha tillit til at profesjoner og godt kvalifiserte profesjonsutøvere ivaretar både enkeltindividers og felleskapets interesser. De vestlige samfunns måte å tilstrebe at vi alle skal få den rettmessige behandlingen vi har krav på, i utdanning, helse, omsorg eller andre samfunnstjenester, er ved å kreve høy formell utdanning og sertifisering av profesjonelle fagfolk. I tillegg forutsettes det at profesjonelle aktører lever opp til sin profesjons internt definerte faglige og etiske standarder (Abbott 1988; Durkheim 1957/2001; Grimen 2005; 2008; Freidson 2001; Parsons 1951; 1968; Sullivan \& Rosin 2008). En slik «samfunnsstyring» forutsetter altså profesjonelle aktører som både ønsker og er i stand til å vurdere hva som er beste løsning, behandling eller lignende for klienten eller pasienten - ut fra en vurdering av enkeltindividets behov og samfunnets interesser (Evetts 2006; May 1996; Scott 2005).

Samtidig erfarer vi at det å ta et profesjonelt ansvar og opptre yrkesetisk forsvarlig i et komplekst samfunns- og arbeidsliv, er krevende. Mulighetene for å leve opp til formelt definerte etiske profesjonelle standarder, er sterkt utfordret $i$ en tid preget av et kulturelt mangfold og ikke minst et effektivitetskrav basert på «nyliberal tenkning og fleksibel kapitalisme» som i mange tilfeller setter økonomiske nyttehensyn foran de moralske. Det normative ideal om å «tjene andre» møter hard konkurranse i vår tid der ideer om selvfremstillelse og individuelle prestasjoner som blir målt mot økonomiske kriterier, har dominans (Gardner et al. 2001; Komulainen 2006; May 1996; Sennett 1998). Dessuten har i dag mange «brukere» av profesjonelle tjenester et generelt høyt kunnskapsnivå som de tar med seg inn i møtet med profesjonelle aktører. Informasjon og kunnskap som tidligere var monopolisert av profesjonene, som for eksempel medisinsk kunnskap, jus og lignende, er i økende grad gjort tilgjengelig for legfolk blant annet via Internett (Castells 2000; Tjora 2008). Den klassiske paternalistiske profesjonell-klient-relasjonen som til dels den normative forståelsen av profesjonsansvaret hvilte på (f.eks. Durkheim og Parsons) er i dag utfordret. Stadig flere klienter hevder sin rett til å forhandle med den profesjonelle om hva som er den beste løsningen i hvert enkelt tilfelle (Tjora 2008). En slik forhandling må bygge på at den profesjonelle klarer å utvise «god» dømmekraft og samhandler konstruktivt med sine «brukere» (Ruyter 2005). Senmoderne samfunn fordrer kort sagt at profesjonelle aktører i sin hverdagspraksis evner å håndtere komplekse og relasjonelle problemstillinger samtidig som de etterlever høye faglige og moralsk standarder (May 1996). Hvordan profesjonelt ansvar og yrkesetikk læres, forstås og leves ut i praksis, er derfor ikke likegyldig verken for oss som enkeltindivider eller for samfunnet som helhet.

Med dette som utgangspunkt, vil jeg drøfte hva vi mener med yrkesetikk, og hvordan formell grunnutdanning kan legge til rette for at kom- 
mende profesjonelle aktører skal kunne utvikle en reflektert bevissthet omkring sitt fremtidige yrkesetiske ansvar. ${ }^{2}$ Jeg har valgt å se på hvordan vi kan forstå yrkesetikkens forankring og funksjon, og hva forskningen kan fortelle oss om læring av yrkesetikk. Artikkelen starter med en teoretisk drøfting av begrepene etikk, moral og profesjonsetikk. Videre presenterer og drøfter jeg noen empiriske funn som viser oss hvordan yrkesetiske spørsmål er blitt behandlet i høyere grunnutdanning, og hvordan nyutdannede opplever yrkesetikk i praksis. Litteraturen jeg viser til, er preget av det utgangspunktet jeg har i egen forskning på utdanning til profesjonelt ansvar (Solbrekke 2007), samtidig som jeg her inntar et bredere blikk, ved å hente inn empiri fra andre profesjoner. Den utvalgte litteraturen gir ikke et fyllestgjørende bilde av hvordan høyere utdanning jobber med yrkesetisk bevissthet og handlingsberedskap, men funnene fra disse ulike utdanningsprogrammene og profesjonene bidrar med interessante indikasjoner som kan øke vår innsikt i hvordan høyere utdanning kan legge til rette for utdanning til moralsk handlingsberedskap. På den bakgrunn vil jeg avslutningsvis peke på noen kritiske faktorer i læring av yrkesetikk som basis for en reflektert moralsk handlingsberedskap.

\section{En okende interesse for moral, etikk og yrkesetikk}

Fokus på yrkesetikk har økt de senere årene (Christoffersen 2005: 9), blant annet som en konsekvens av en generell interesse for etikk som startet $i$ 1980-årene da etikk, moral og verdier ble sentrale ord i offentlige debatter. De fleste husker verdikommisjonen som Bondevik-regjeringen nedsatte. Og selv om den gav grobunn for både ironi og gode historier, bidro den til et økt fokus på etikk og moral i sin alminnelighet. Spørsmål som hvordan datateknologi kunne brukes til det beste for alle borgere, eller til hvilke formål genforskningens muligheter skulle anvendes, eller hva som ble sett som den beste pleie av syke, vokste frem som moralske problemstillinger som krevde grundige etiske overveielser. Slike utfordringer har altså ført til at etikk i sin alminnelighet, men i sær profesjonsetikken, er blitt satt tydeligere på dagsorden, men da oftest i forbindelse med de «menneskebehandlende» profesjoner, dvs. yrker hvor den profesjonelle jobber med mennesker og står i direkte relasjon til en klient eller pasient, f.eks. jurister, psykologer, lærere, leger, sykepleiere og andre helse- og sosialarbeidere (Christoffersen 2005: 14). Det er innenfor disse yrkene at kvaliteten på den tjenesten vi mottar, eller behandlingen vi utsettes for, får en umiddelbar konsekvens for den enkelte av oss. Men yrkesetikken er like viktig for profesjonelle som jobber for mennesker, gjennom mer indirekte relasjoner. Forskeres og ingeniørers handlinger virker inn på menneskers livskvalitet og ikke minst samfunnets utvikling. Det fordrer etiske vurderinger, og det registreres en 
$ø$ kende bevissthet om yrkesetikk også blant disse yrkesgruppene. Et nettsøk på «professional ethics» leder oss for eksempel rett til yrkesetikk for informasjonsteknologer (Elci 2006). Den stigende interessen for yrkesetikk kan også forstås som en konsekvens av behovet for en felles identitetsbygger som gir den enkelte profesjonsutøver noe å navigere etter (Taylor 1989; Ylijoki 2000). I en tid som preges av pluralisme og der yrkesliv er under sterkt press fra mange interessegrupper, trenger profesjonene kanskje mer enn noen gang felles definerte yrkesregler som kan fungere retningsgivende for utvikling av handlingsberedskap i praksis (Nygren \& Fauske 2004: 57). ${ }^{3}$

Samtidig opplever vi at etikkbegrepet dukker opp i sammenhenger som medvirker til at meningsinnholdet flyter ut. Det blir i økende grad brukt som «salgsvare» på flere områder. Når kommersielle bedrifter, så vel som offentlige institusjoner, ønsker å legitimere sin virksomhet, profilere og «selge» seg som moralske leverandører av «etisk forsvarlige» produkter og tjenester, kan dette bidra til en utydeliggjøring av hva vi mener med etikk og moral. Så hva mener vi da, når vi snakker om at profesjonelle handlinger må være etisk forsvarlige, eller at en profesjonsutøver handler moralsk?

Etikk og moral er begrep som ofte brukes om hverandre i dagligtale, og de handler begge om menneskelige handlinger. Det kan imidlertid være nyttig å skjelne noe mellom dem når vi skal se på dem i en faglig sammenheng. En vanlig distinksjon er slik Christoffersen (2005: 10) uttrykker den:

\footnotetext{
Moral er noe som kommer til uttrykk først når vi gjør noe. En handling ses som moralsk når vi handler ut fra det vi mener er rett og riktig. Vi spør altså om en handling er riktig eller gal. Etikken dreier seg om de regler og normer vi bruker i moralske

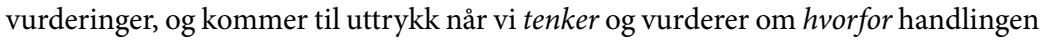
er gal eller riktig.
}

Generelt sagt er altså etikk moralens teoretiske grunnlag, så gjennom etiske overveielser kan en utvikle en moralsk bevissthet omkring sine handlinger. Men hva er så det spesifikke ved profesjons- eller yrkesetikk? ${ }^{4}$

\section{Yrkesetikkens forankring}

Det er vanlig å se yrkesetikk som en forlengelse av allmennmoralen eller tilpasning av allmennetikk til et yrkesområde (Colnerud 1995: 16; Tranøy 1998). Dette er imidlertid et standpunkt som profesjonsetikeren Grimen $(2005 ; 2008)$ problematiserer. I 2005 tok han initiativet til en debatt på nettsidene til Senter for profesjonsstudier ved Høgskolen i Oslo, som har ført til engasjement i spørsmål om profesjonsetikkens forankring og derved også hvordan dens primære mandat skal forstås.

Grimen argumenterer for at vi må forstå yrkesetikk i lys av at profesjoner er sosiale sammenslutninger som er gitt politisk legitimitet for et sam- 
funnsoppdrag. Derfor, hevder han, er profesjonsetikken primært forankret i det politiske grunnlaget for et definert samfunnsoppdrag og ikke i en forlengelse av allmennmoralen, selv om mange av de profesjonsetiske normene er ganske analoge med allmennmoralen (Grimen 2005: 3). Allmennmoralen kan for eksempel si at vi skal hjelpe nødstilte. Men at moderne samfunn velger å organisere denne hjelpen gjennom ved å opprette profesjoner og utdanne profesjonsutøvere til å fylle slike hjelpefunksjoner, er ikke direkte avledet av en allmennmoralsk norm, men bestemt som en historisk størrelse ut fra et organisatorisk og politisk kriterium (Grimen 2008: 156f). Yrkesetikk gir seg derfor uttrykk i spesifikke moralske handlinger som er forankret i det politisk bestemte samfunnsoppdraget som den respektive profesjon er gitt med utgangspunkt i profesjonens kjernekunnskap. Av dette følger at det er det politiske mandat som definerer de etiske normene som skal virke handlingsveiledende for de profesjonelle yrkesutøverne, samtidig som disse reglene skal fungere som et vern mot uetisk atferd for den enkelte samfunnsborger. Slik blir samfunnsborgernes perspektiv det primære og ikke den enkelte profesjonelle utøvers personlige vurdering (Grimen 2005: $1)$.

Å forstå yrkesetikkens politisk motiverte kodekser kan være en hjelp når allmennmoralen som ligger til grunn for den personlige etikk vi utvikler, i visse situasjoner kan stå i konflikt med de profesjonsetiske vurderingene vi må foreta og den profesjonsmoralen som må utøves. Som eksempel kan vi ta en situasjon der leger er nødt til å påføre en pasient smerte for å gjøre ham eller henne frisk (jf. Grimen 2008). Dette vil stride mot allmennmoralen, som sier at vi ikke skal plage andre mennesker. Men her vil den profesjonsetiske verdi som ligger til grunn for profesjonsmoralen, handle om å følge normer og standarder vi setter for profesjonelt arbeid; i dette tilfellet å måtte gi en smertefull behandling som profesjonsutøveren legen mener er til det beste for pasienten, selv om legen som medmenneske ifølge en allmennmoral ikke skal påføre et annet individ smerte. Med dette skiller altså profesjonsmoralen seg tydelig fra allmennmoralen. For mens det å handle i tråd med allmennmoralen er et mål i seg selv, må profesjonsmoralen her forstås som et middel for et annet formål; å gjøre pasienten frisk.

En annen forskjell mellom allmennmoral og profesjonsmoral er at mens allmennmoralen gjelder oss alle, vil profesjonsmoralen kun gjelde profesjonsutøvere som er kvalifisert til å utføre de spesifikke oppgavene en profesjon er tildelt gjennom sitt samfunnsoppdrag. Følger vi Grimen, betyr dette at vi må se den enkelte profesjonsutøvers handlinger i lys av det politiske mandatet han eller hun er gitt på vegne av den profesjonen de er medlem av. Å være en profesjonell utøver betyr altså at en ikke opptrer på vegne av seg selv, men som representant for en profesjon. Det betyr at om ens egen etikk kommer i konflikt med profesjonsetikken, må ens egen etikk settes til side, eller en må være villig til å ta problemstillingen opp med sin profesjon. 
I dette ligger et handlingsrom for den enkelte til selv å ta ansvar for en kritisk vurdering av profesjonsetikken. Men, en slik kritikk må like fullt forholde seg til at profesjonsetikken bygger på den politiske legitimiteten til det samfunnsoppdrag som profesjonen er bærer av (Grimen 2008).

Grimen reiser, etter mitt syn, noen prinsipielle problemstillinger som er viktige når den enkelte profesjonsutøver skal utvikle en bevissthet om egen yrkesetikk. Å vite at en representerer en profesjon som en sammenslutning, tydeliggjør at den enkelte utøver er medlem av et fellesskap med et spesifikt mandat. Gjennom dette forpliktes en til en etikk som ikke alene er ens personlige, men forankret i et kollektivt ansvar.

Andre profesjonsetikere problematiserer imidlertid Grimens syn som forankrer etikken primart i politikken (f.eks. Christoffersen 2005; Nortvedt 2005). Disse mener at Grimen har et viktig poeng når han minner oss om den politiske dimensjonen all yrkesetikk har. Å være bevisst denne kan bidra til å utvikle en motkraft til konkurrerende ideologier som f.eks. setter egeninteresser foran kollektive behov. Likevel hevder for eksempel Nortvedt at yrkesetiske overveielser må, i likhet med all etikk, springe ut fra en intuisjon som er «andreorientert». Det er ikke i første rekke gjennom rasjonelle kontrakter og vurderinger at etisk ansvar utvikles. Det er gjennom den grunnleggende evne til å se en persons lidelse og behovet for å hjelpe andre som trenger det, at etikken skapes (Nortvedt 2005; 2006). Det fordrer en grunnleggende forstålse for den etiske dimensjonen som ikke er skapt av en gjennomtenkt rasjonell prosess, karakteristisk for det politiske samfunnsoppdrag, men på personlig sensibilitet for andres behov.

Selv om Christoffersen (2005: 37) støtter Grimens betoning av en bevissthet om profesjoners samfunnsoppdrag, understreker han også tydelig betydningen av at vi fremholder det personlige ansvar i yrkesetikken. At profesjonene har et oppdrag og mandat fra samfunnet, betyr ikke at profesjonsetikken helt og holdent er eksternt forankret, hevder han. Det er ikke nok bare å henvise til hva som er politisk bestemt, og hva en er pålagt utenfra. Yrkesetiske handlinger må forankres i hva som fremstår som moralsk riktig og ansvarlig i henhold til både et politisk mandat og etiske vurderinger.

For oss som ikke er profesjonsetikere, kan kanskje denne debatten fremstå som noe abstrakt. Jeg mener likevel at den er viktig å forholde seg til i utdanning av profesjonsutøvere. Uavhengig om man mener at yrkesetikk er primoert forankret $\mathrm{i}$ et politisk mandat eller i etikk, illustrerer debatten behovet for en bevissthet om at yrkesetikk er både et politisk og et etisk anliggende. Det dreier seg om å forstå hvordan profesjonsmoralske handlinger favner mer enn den konkrete klient-profesjonell-relasjonen og andre lokale forpliktelser i forhold til kollegaer og arbeidsgiver. I dette ligger blant annet at samfunnet, som i siste instans er profesjonenes oppdragsgiver, kan forvente at profesjonene skal sørge for å virke som en medierende kraft og 
beskytter av enkeltindividenes behov så vel som samfunnets interesser (jf. Durkheim 1957/2001; Parsons 1951).

Sammenfattet kan vi si at utvikling av en reflektert og holistisk forståelse av yrkesetikk innebærer å legge til rette for kommunikative handlinger der deliberasjon om politiske og etiske avveininger inngår. For, som Nortvedt (2005: 1) understreker; selv om den formen for etikk som springer ut fra en «andreorientering» ikke primært skapes i rasjonell deliberasjon, videreføres den gjennom kommunikativ rasjonalitet.

Hvordan blir så yrkesetisk ansvar nedfelt og forsøkt ivaretatt?

\section{Yrkesetikkens ulike dimensjoner og funksjon i praksis}

Det politiske samfunnsoppdraget nedfelles gjerne i et sett av regler som skal tydeliggjøre og ivareta profesjonens formelle oppgaver og ansvar (Abbott 1983; Durkheim 1957/2001; Grimen 2008; Parsons 1951; 1968). Disse skal kunne gjenspeiles i de yrkesetiske reglene som er definert av den enkelt profesjon og som setter standarden for hva som oppfattes som faglig og etisk godt arbeid i henhold til profesjonens spesifikke samfunnsoppdrag. Slik sett har yrkesetiske retningslinjer ideelt en disiplinerende funksjon og legger grunnlag for en intern selvkontroll som er basert på at andre profesjonelle som er faglig kvalifisert, kan utføre en kollegial kontroll i forhold til standarder for god praksis (Freidson 2001; Nygren \& Fauske 2004). Yrkesetiske regler skal fungere som en garanti for at profesjonsaktørenes og profesjonsgruppens egeninteresser blir holdt i sjakk, og at alle «brukere» av profesjonelle tjenester til enhver tid får den best mulige behandling samtidig som at samfunnets interesser ivaretas. Et slikt pålegg gjelder alle yrker som krever en spesialisert kompetanse, og der både profesjonen og den enkelte profesjonelle aktør skal utøve en tjeneste for andre i henhold til et visst moralsk ideal på en moralsk forsvarlig måte (Davis 2002: 3, sitert i Ruyter 2005: 111).

Men profesjonelle yrkesutøvere er, som argumentert over, ikke bare styrt av profesjonsdefinerte regler. At profesjonsutøvere har et klart personlig etisk ansvar betyr at den enkelte aktør må svare for egne handlinger (Christoffersen 2005: 13). Dette ansvaret blir spesielt aktuelt i kravet om å handle til enkeltklientens beste. Det kan f.eks. være i spørsmål om hva som er det beste behandlingstilbudet for en pasient, og der profesjonsutøveren er den som har ansvar for å skape tilliten som skal til for å finne hva som er «det beste» innenfor de konkrete alterantivene som finnes (Downie \& Jodalen 1997). En slik tillit bygger på godt faglig skjønn, men ikke minst på den personlige etikken som springer ut fra en ansikt-til-ansikt-etikk (Levinas 1988). En grunnleggende tillit er avhengig av profesjonsutøverens evne til empati (Christoffersen 2005), men bygger også på en bevissthet om den 
moralske basis i ens profesjonelle mandat (Sockett 1993). Som yrkesutøver må en ta stilling til hvilke hensyn som skal veie tyngst dersom enkeltindividers behov står i konflikt til andres interesser (Slettebø 2006). Et eksempel er når en lærer må ta stilling til hva som tjener en elev best der skolen og foresatte har ulik forståelse av hva «god» undervisning er. Da må en profesjonell aktør «fremforhandle legitime kompromisser» med utgangspunkt i profesjonens faglige og etiske ansvar (May 1996).

Oppsummert kan vi si at noen av de yrkesetiske normene som styrer våre moralske handlinger, er eksplisitte som absolutte regler, mens andre uttrykkes i prinsipper som beskriver et ansvar, uten å gå i detalj. De sistnevnte fordrer at man kan kombinere faglig skjønn med selvstendige og kloke vurderinger, forankret i god dømmekraft som bygger på moralsk sensitivitet, erfaringskunnskap og teoretisk kunnskap (Nortvedt 2006: 69). I yrkesetikken blir slik dømmekraft gjerne forstått som det Aristoteles kalte phronesis; en evne til praktisk vurdering som leder til valg av rett handling $\mathrm{i}$ en gitt situasjon (Bergem 1993; Colnerud 1995; Gustavsson 2004; Sullivan 2005).

Men hvordan læres og leves yrkesetikk ut i den enkelte profesjon og av den enkelte yrkesutøver? Hva sier forskningen?

\section{Forskning på læring av yrkesetikk}

Før jeg presenterer og drøfter ulike forskningsbidrag, er det verdt å merke seg at empirisk forskning om loering av yrkesetikk er et ganske upløyd forskningsfelt. Med det mener jeg at det er mye normativ litteratur som definerer yrkesetikk og hvordan denne bør etterleves (f.eks. Abbott 1983; Christoffersen 2005; Downie \& Jodalen 1997; Durkheim 1957/2001; Freidson 2001; Parsons 1951; 1968; Slettebø \& Nortvedt 2006), mens empiriske studier av hvordan profesjonsstudenter og aktører faktisk loerer yrkesetikk, er det mindre av. Der finnes studier som har målt studenters moralske modning gjennom høyere utdanningsløp (se f.eks. Loui 2005; Solbrekke 2007a: 45-47), men disse er i liten grad knyttet til profesjonsetiske forhold. Der er imidlertid de senere år registrert en økende interesse i å finne ut mer om hvordan studenter lærer og yrkesutøvere praktiserer sin yrkesetikk (f.eks. Bebeau 1993; Bergem 1993; Colnerud 1995; Freidson 1970/1988; Gardner et al. 2001; Hoshmand 1998; Jensen et al. 2005; Loui 2005; Nygren \& Fauske 2004; Myyry 2003; Sullivan 2005; Tirri 2003a; 2003b; Solbrekke 2007a).

Jeg har valgt å se på forskning om yrkesetikk og undervisning som direkte eller indirekte innvirker på utvikling av yrkesetiske holdninger. Forskningsbidragene som blir referert her, nærmer seg studier av moralsk utvikling på noe ulikt vis. Flere kognitiv-utviklingspsykologiske studier er 
inspirert av Kohlbergs (1984) moralske stadieutvikling (f.eks. Bebeau 1993; Bergem 1993; Colnerud 1995; Myyry 2003), mens andre tar utgangspunkt i profesjonssosiologiske tilnærminger (f.eks. Abbott 1983: 857; Alford 2001; Freidson 1970/1988) og/eller filosofiske og sosiokulturelle læringsteoretiske perspektiver (Gardner et al. 2001; Jensen \& Tveit 2005; Nygren \& Fauske 2004; Solbrekke 2007). Slike ulike vitenskapsteoretiske tilnærminger vil føre til noe forskjellig oppmerksomhetsfokus. Det kan berike vår forståelse av feltet, men innebærer også noen distinksjoner som en skal være klar over. Disse vil imidlertid ikke bli drøftet i denne artikkelen. Intensjonen her er heller å bruke funn fra ulike perspektiver og profesjonsfelt til å belyse hva som stimulerer eller svekker læring og praktisering av yrkesetikk i praksis, og derigjennom identifisere noen felles og kritiske faktorer.

\section{De ulike bidragene}

Innenfor lærerforskning finnes det flere studier fra slutten av 1980- og videre på 90-tallet med fokus på problemstillinger knyttet til læreres moralske bevissthet og handlekraft. Særlig sentral i norsk kontekst er Bergems studie av læring av yrkesetikk (Bergem 1993). Dette er en studie som selv om den ble foretatt i 1986 og 1988, er blitt stående som en av de mest refererte blant empiriske studier av yrkesetikk. ${ }^{5}$ Jeg vil derfor beskrive denne noe nærmere fordi den presenterer sentrale funn og i tillegg refererer en forskningstilnærming som er mye brukt i læring av moralsk resonnering som del av yrkestisk handling også i annen profesjonsutsutdanning.

Bergems utgangspunkt er forankret i den normative etiske fordring som ligger i en pedagogisk situasjon. Hans teoretiske resonnement er inspirert av moralutviklingsforskeren Oser, som hevder at tilliten til skolen og dens lærere er fundert $i$ at den enkelte ansatte utvikler en yrkesetisk rasjonalitet for sin yrkesutøvelse (Oser et al. 1991 i Bergem 1993: 33). Med det menes at lærerens handlingskompetanse må bygge på både en yrkesetisk og didaktisk rasjonalitet, der den yrkesetiske rasjonaliteten søker etiske begrunnelser og fungerer som støtte til den didaktiske rasjonaliteten (Bergem 1993: 36). Slik jeg tolker Bergem, har dette relevans for alle profesjoner. En moralsk handlingsberedskap innebærer en bevissthet om at den yrkesetiske rasjonalitet alltid må/skal støtte og korrigere enhver faglig rasjonalitet.

Bergem forutsetter i sin undersøkelse at lærernes grunnutdanning kan $ø$ ke yrkesetisk bevissthet. For å undersøke dette ble det gjennomført både kvantitative og kvalitative studier som skulle måle effekt av undervisningstiltak på utvikling av moralsk resonnement og samsvar mellom moralsk tenkning og moralsk atferd. 342 lærerstudenter, 14 pedagogikklærere og 48 øvingslærere ved flere høgskoler deltok. Det teoretiske grunnlaget for analysene var inspirert av Rests prosessmodell - en modell som har dannet 
grunnlag for flere studier også i andre profesjonsfelt (f.eks. Bebeau 1993; Myyry 2003). Jeg vil komme tilbake til noen av disse studiene.

I denne modellen (bygget på Rest 1984: 27 i Bergem 1993: 165) vektlegges både kognitive og emosjonelle prosesser som kan lede til handling.

1 Sosiomoralsk sensitivitet: Evne og vilje til å sette seg i en annen persons sted og til å oppfatte yrkesetiske utfordringer

2 Moralsk tenkning: Evne til å analysere moralske dilemmaer og vurdere konsekvenser av handlinger

3 Moralsk motivasjon: Vilje til å gjennomtenke og utforme konkrete planer for handling

4 Implementering: Evne og karakterstyrke til å handle i samsvar med egen overbevisning

I Bergems forskning ble det fokusert på hvordan lærerutdanningen konkret påvirket lærerstudenters yrkesetiske bevissthet. Resultatene viste imidlertid at lærerstudentene i liten grad utviklet en bevissthet omkring sitt yrkesetiske ansvar, selv om de gjennom studiet utviklet en økt refleksjon omkring lærerrollen. De manglet et språk for yrkesetikk, og de fleste sa at bortsett fra taushetsplikten, så forbandt de ikke noe med det. En av de få som forsøkte å gi begrepet et innhold, sa følgende:

Jeg lurer på om vi ikke så vidt har touchet borti det. Men lærere - har de noen yrkesetikk, holdt jeg på å si. Det finnes vel ikke noe reglement for læreres yrkesetikk. [...] Det finnes derimot en hel rekke uskrevne regler og normer som samfunnet pålegger oss å følge og som vi pålegger hverandre å følge. Men vi har touchet veldig lite inn på det. (Kvinnelig lærerstudent, sitert i Bergem 1993: 264)

Dette utsagnet viser en lav grad av yrkesetisk bevissthet samtidig som den indikerer det «usikre» $\mathrm{i}$ at lærerprofesjonen ikke har standardiserte yrkesetiske retningslinjer. Det viser videre at lærerutdanningen ikke hadde behandlet yrkesetikk tilstrekkelig - på tross av at det lå i de politiske føringene at lærerutdanningen skal «[...] leggje vekt på å fremje yrkesetisk holdning» (Bergem 1993: 208). I denne studien ble det også klart at heller ikke lærerutdannerne hadde en uttrykt bevissthet om egen yrkesetikk.

En amerikansk studie fra 1993 som så på læreres moralske påvirkning på elever, indikerer at lærerne var overraskende lite bevisste på sine handlingers konsekvenser og moralske tyngde (Jackson et al. 1993 i Colnerud 1995: 22f). En kanadisk studie, også denne fra 1993, som studerte læreres og skolelederes bevissthet om potensielle konflikter mellom deres personlige moral og skoleorganisasjonens behov, viste at både lærere og skoleledere hadde problemer med å artikulere det moralske ansvaret og handle i overensstemmelse med sin moralske overbevisning - særlig om disse var i 
strid med kollegaers interesser eller skoleorganiseringen (Campbell $1993 \mathrm{i}$ Colnerud 1995: 23).

Det kan være fristende å trekke konklusjoner om svakt moralsk engasjement på grunnlag av disse nevnte studiene. Det er det imidlertid ikke grunnlag for. Studiene viser at mange lærere har et moralsk engasjement $\mathrm{i}$ jobben sin, men problemet er at det er lite felles refleksjon omkring disse spørsmålene, og de fleste mangler et språk for å artikulere sin yrkesetikk. Dette kan forstås blant annet $\mathrm{i}$ lys av at lærere ikke har et felles sett yrkesetiske retningslinjer, men at profesjonen likevel ser utdanning som et moralsk ansvar. Det er en diskusjon som ikke kan forfølges her, men som kan danne grunnlag for en videre problematisering av hva en mener med yrkesetikk i praksis.

Manglende yrkesetisk vokabular bekreftes også i annen forskning på lærerutdanning og utvikling av yrkesetisk bevissthet. En svensk studie fra 1995 viser hvordan svenske lærere opplever sine yrkesetiske konflikter i grunnskolen. Funnene viser at yrkesetikk er et sammensatt og komplekst begrep, og at læreres handlinger er påvirket av mange faktorer og normer som de er mer eller mindre klar over, og som de har vanskelig for å verbalisere. Disse stammer fra så vel etiske normer som profesjonsinterne normer, faginterne normer, institusjonelle normer, sosiale normer og selvbeskyttende normer (Colnerud 1995). Resultatene fra studien sier imidlertid ikke noe eksplisitt om hvordan lærere loerer yrkesetikk, men ved å problematisere de etiske konfliktene de står i, tegnes det et bilde av at utvikling av læreres handlingsmønstre er overlatt til den enkelte lærer og ikke systematisk behandlet i grunnutdanning eller i praksis i skolen. Videre viser funnene at lærere er styrt av lokal praksis og et yrkesetos som legger restriksjoner på dem i forhold til å kritisere hverandre. Blant annet bidrar en forventet sterk kollegial lojalitet til at varsling om uetiske forhold, «whistle-blowing» (Bok 1988), sjelden forekommer (Colnerud 1995). Disse funnene harmonerer med nyere forskning på whistle-blowere, som viser hvordan en kollegial «lojalitet» eller «maktutøvelse» gjør det vanskelig å stå frem som varsler (Alford 2001).

At en sterk kollegial «lojalitet» dominerer, blir bekreftet også i studier fra andre profesjoner. Flere funn viser at profesjonelle aktører generelt later til å la yrkesetikken og hensyn til pasient eller klient vike når forpliktelsen til kollegaer «krever» det (Abbott 1983: 862).

Amerikanske studier av praktiserende leger viser at lokale forhold på arbeidsplassen og uformelle normer og verdier påvirker og regulerer en praktikers handlinger mer enn formelle yrkesetiske koder (Abbott 1983: 857; Freidson 1970/1988: 181). 


\section{Den lokale kulturs dominans - og motstridende verdier}

At den lokale kultur og praksis i sterkest grad påvirker profesjonsutøveres handlinger, finner vi også i en nyere norsk empirisk forskningsstudie som ser på hva som former profesjonsutøveres beredskap til å handle i tråd med ulike verdier og ideologier (Nygren \& Fauske 2004: 17). Kryssildprosjektet (2006), som pågikk i perioden 2000-2004, så på læring og utvikling av profesjonelle handlingskompetanser innen det helse- og sosialfaglige feltet. Den konkluderte med at lojalitet til kollegaer og det lokale arbeidsstedet blir rangert som viktigere enn f.eks. lojalitet til velferdsstatens verdier (Nygren \& Fauske 2004: 159).

Forskningen i dette prosjektet viser i tillegg hvordan både tidligere livserfaringer og den posisjon en har i ulike praksisfellesskap, har betydning for hvilke yrkesetiske prioriteringer som foretas. I likhet med hva profesjonsforskeren Abbott tidligere har hevdet (1988), at maktforhold spiller inn og påvirker den individuelle aktørs muligheter for å handle etter egen overbevisning, viser også Nygren og Fauske at den enkeltes yrkesetiske handlingsmuligheter påvirkes av både jobbstatusen, formelle strukturer og uformelle maktforhold. På grunnlag av sine funn og fokus på læring gjennom deltagelse i praksis understreker forskerne videre at vi må forstå læring av yrkesetikk som det som skjer gjennom aktiv deltagelse i ulike former for sosiale praksisfellesskap, og som et resultat av forhandlinger av profesjonens universelle regler og de verdier og begrunnelser som preger den lokale yrkeskonteksten (Nygren \& Fauske 2004). Funn fra studier på psykologi- og jusstudenters oppfatninger av profesjonelt ansvar i overgangen fra utdanning til yrkesliv viser tilsvarende funn (Solbrekke 2008). En ung kvinnelig jurist fortalte at hun hadde fătt et bevisst etisk ansvar gjennom deltagelse i ideelt arbeid i Amnesty og fri rettshjelp mens hun studerte, men hun viste en endring etter et år i arbeid. Som siste års student hevdet hun at klientens interesse alltid må gå foran de økonomiske, mens etter et år som advokatfullmektig og i samhandling med sine kolleger, var hun begynt å tvile på om hennes moralske idealer hadde vært for høye eller urealistiske.

Lignende resultater som viser hvordan den lokale kulturen spiller inn, finner vi i det amerikanske forskningsprosjektet GOOD WORK ${ }^{6}$ (19962006), med paralleller til danske studier (Knoop ved DPU) ${ }^{7}$. Forskningen omfattet intervjuer av etablerte og vellykkede profesjonelle aktører og av nyansatte innenfor mange ulike profesjonsdomener. De ble spurt om hva de definerte som godt arbeid, og hvordan de bestrebet seg på å leve opp til yrkesetiske standarder (Gardner et al. 2001). Samlet sett viser disse studiene at selv om de fleste profesjonsutøvere aspirerte til å gjøre et godt arbeid og etterleve profesjonens idealer, presser dagens krav om økt effektivitet og økt markedsøkonomisk tenkning både personlige og yrkesetiske verdier og holdninger. Selv om erfaringene varierte mellom profesjonene, opplevde alle at verdier som ærlighet og integritet, grundighet, åpenhet og fordomsfri 
nysgjerrighet, kritisk tenkning og en genuin sannhetssøkende holdning ble sterkt utfordret da de entret arbeidsmarkedet. Unge yrkesutøvere lærte raskt at det ikke nødvendigvis er overensstemmelse mellom forfektede verdier og praksis (jf. Schön 1982). En ung genforsker som havnet i bioteknisk industri, opplevde raskt at det å være helt ærlig kunne by på problemer:

You have to tread a thin line between being completely honest about something and telling its shortcomings and just talking about what's good about it and hope that they spend their money [...] I'm discovering that in business, ethics [...] are a much more complex thing than I ever realized. (Gardner, Csikszentmihalyi \& Damon 2001: 103)

Men også innenfor akademia ble tradisjonelle vitenskapelige etiske kriterier utfordret. En lovende doktorand opplevde at hennes ideal om grundighet ikke var lønnsomt da hun skulle søke jobb: «It would have been better to have more publications of lesser quality than to have one publication at the end of high quality.» (Gardner et al. 2001: 103).

En tredje ung forsker ansatt ved et stort universitet lærte hvor problematisk det er å ta ansvar på alvor da han varslet om uetiske forhold på jobben. Han gjengir en episode der han fortalte lederen for det medisinske fakultet om dobbelfinansiering av et forskningsprosjekt. Han ble takket for at han sa ifra, men erfarte i ettertid at ikke noe skjedde med saken, men at han selv fikk mer marginale posisjoner i forskningsgruppen. Denne erfaringen gjorde at han lærte mye om den risikoen det er å etterleve yrkesetikk i praksis (Gardner et al. 2001: 104). Eksemplene fra genforskerne viser at selv i miljøer som er relativt beskyttet fra eksterne markedskrefter og krav om umiddelbar økonomisk vinning, er det vanskelig å etterleve de yrkesetiske idealene i praksis. Lokale forhold og relasjoner veier tyngre enn samfunnspolitiske oppdrag og etiske aspekt.

Resultater fra journalistene i GOOD WORK-prosjektet viser at disse i større grad enn akademikere utfordres til å fravike sine idealer i en yrkeskontekst. De tradisjonelle verdiene som særlig etablerte journalister med en sterk integritet vektlegger - å være saklig, aldri lyve, undersøke og verifisere fakta, være objektiv og gi balanserte fremstillinger, representere og presentere alle borgere likeverdig og med respekt, la alles meninger få slippe til og plassere fakta i sin rette kontekst - er sterkt truet av markedskreftene og en økende underholdningsindustri. De få som greide å leve opp til sine personlige yrkesetiske standarder, jobbet som regel i miljø der profesjonens misjon ble holdt oppe, diskutert og hvor etablerte fagfolk selv etterlevde de yrkesetiske prinsippene (Gardner et al. 2001; Fishman et al. 2004).

Oppsummert viser den gjengitte forskning at læring og utvikling av en yrkesetisk handlingskompetanse i sterk grad overlatt til den individuelle aktør i utdanning og yrke. I tillegg er det manglende yrkesetisk språk. ${ }^{8}$ Videre ser vi at kontekstuelle forhold og lokale kulturer og verdier ofte står 
i spenning til eller utfordrer universelle yrkesetiske idealer. Spørsmålet blir da om utdanning kan bidra til å legge grunnen for en moralsk handlingsberedskap til hjelp ut i arbeidslivet. Hva forteller forskningen om dette?

\section{Utdanningens bidrag}

Forskningen på lærere indikerer som vist at nyutdannede er dårlig rustet til å møte yrkesetiske konflikter, og GOOD WORK-forskningen innenfor andre profesjoner viser det samme. De fleste opplevde å være dårlig forberedt på kompleksiteten i det yrkesetiske ansvar og de moralske dilemmaene de blir konfrontert med på jobb. Et slikt inntrykk bekreftes også i en annen studie som bygger på historier fortalt av etablerte og dedikerte amerikanske psykologer (Hoshmand 1998). Det tyder på at selv innenfor et fag som psykologi, der sentrale verdier som ydmykhet, respekt og empati og de formelle yrkesetiske retningslinjer og nasjonale standarder for psykologer blir behandlet spesielt i utdanningen, oppleves denne forberedelsen som utilstrekkelig når det gjelder de komplekse moralske og samfunnsrelaterte utfordringene som arbeidslivet representerer. Også nyere studier av psykologistudenter ved Universitetet i Oslo indikerer at yrkesetiske spørsmål i for sterk grad begrenses til «lovregulerte» forhold i relasjonen mellom kliniker og pasient (Solbrekke 2007a).

Nafstad (2005) hevder at etikkundervisningen i psykologiutdanningen er for ensidig orientert mot foreskrivende regler og hvordan en som profesjonsutøver ikke skal misbruke sin stillings- og kompetansemakt. Dette er selvfølgelig viktige forhold å drøfte, men ikke tilstrekkelig, hevder Nafstad (2005: 158). Nafstad argumenterer for at en yrkesetisk forståelse også må innebære en moralsk og etisk sensitivitet som utvikles ved at fagets og begrepenes underliggende verdier og konsekvenser av psykologisk praksis kritisk analyseres. En slik tilnærming kan gjøre studentene mer bevisste på hvordan deres fag og profesjonelle bidrag kan tjene både den individuelle klient og samfunnet.

Jeg mener Nafstad peker på noe vesentlig. Funn fra egen forskning viser at på tross av at psykologistudenter ved Universitetet i Oslo hadde erfart at yrkesetiske spørsmål var satt på dagsorden i studiet, pekte de også på enkelte mangler (Karseth \& Solbrekke 2006; Solbrekke \& Jensen 2006). Selv om de fleste hadde lært yrkesetikk ved å observere gode og mindre gode rollemodeller, og de hadde fått respons på egen atferd fra både pasienter og veiledere i praksis, var det mer tilfeldig om de hadde fått erfare yrkesetiske konflikter. Noen mente også at det var vesentlige forhold som ikke ble behandlet i det hele tatt. Blant annet ble det kommentert at empati som en «god» verdi ikke var blitt problematisert (Solbrekke 2007a). 
Med bakgrunn i disse forskningsfunnene tyder det på at læring av yrkesetikk er en dimensjon som ikke blir tilstrekkelig ivaretatt i profesjonsutdanninger. Årsakene til dette kan være flere, og det er vanskelig å gi et klart svar på hvorfor det er slik. Kanskje henger det sammen med at ykesetiske probemstillinger ikke blir systematisk problematisert og prøvd ut i praksis (Sullivan \& Rosin 2008). Kanskje har det sammenheng med at lærere i høyere utdanning rett og slett ikke har en sterk nok bevissthet om de etiske dilemmaer nyutdannede møter i yrkespraksis, eller at de ikke har tid til de prosessene som læring av yrkesetikk krever. Eller kanskje akademikere til dels har unnveket å ta opp verdispørsmål fordi de ikke skal pådytte studenter sine personlige holdninger og verdier (Bok 1986).

Enkelte forskningsbidrag, som for eksempel fra GOOD WORK-prosjektet, viser likevel at nettopp det å snakke om egne verdier, å sette yrkesetiske standarder på dagsorden, og ikke minst å leve dem ut i praksis bidrar til å øke den individuelle beredskap også for nyutdannede (Fishman et al. 2004). Det er derfor helt sentralt at både lærere i høyere utdanning og etablerte profesjonelle aktører prioriterer yrkesetiske problemstillinger. Dessuten må de være bevisste på hvilken påvirkningskraft de har som rollemodeller. I konkret veiledning, i arbeid som i utdanning, men ikke minst i hvordan lærere og erfarne profesjonsutøvere praktiserer sin egen yrkesetikk, gis det sterke normative føringer (Gardner et al., 2001; Nygren \& Fauske 2004; Ruyter 2005). Jeg vil derfor presentere noen eksempler som viser at formell utdanning har positiv innvirkning på læring av moral og yrkesetikk - når det jobbes bevisst med det.

\section{Utdanning nytter}

En finsk doktoravhandling fra 2003 (Myyry 2003: 45) redegjør for internasjonal forskning fra spesielt 1990-tallet og begynnelsen av dette århundret som tar for seg studier på effekten av ulike former for intervensjon for å øke studenters evne til moralsk resonnering - spesielt knyttet til yrkespraksis. Studiene bygger på Rest sin kognitive og emosjonelle prosessmodell. Et gjennomgående resultat fra ulike profesjonsfag viser at pedagogiske tiltak hadde positiv effekt på å fremme studentenes moralske tenkning og handlinger. Særlig profesjonsetiske kurs som hadde en varighet over flere uker og som vektla dilemmadiskusjoner, styrket studentenes ferdigheter i moralsk resonnering - også når det gjaldt handlingsvalg. For eksempel siterer Myyry resultater fra en amerikansk studie på siste års tannlegestudenter (Bedeau et al. 1994 i Myyry 2003: 46) som viser at de som hadde gjennomgått etikkurs, og som koblet dette opp mot sin kommende profesjonelle rolle, var mer villige til å behandle HIV-infiserte pasienter enn studenter som ikke hadde tatt kurset. 
Myyrys egne studier ved Helsinki universitet bekrefter også at moralsk refleksivitet kan læres og utvikles. Blant annet fant de positive gevinster ved å benytte autentiske fortellinger fra sosialt arbeid der studentene skulle forholde seg til moralske spørsmål. Disse åpnet for mange moralske refleksjoner, men det jeg finner mest interessant med tanke på loering av yrkesetikk, er at studien viser at systematisk jobbing med etiske spørsmål ser ut til å øke studentenes refleksive tenkning, men også deres moralske handlekraft som er viktig for å kunne leve opp til senere yrkesetiske krav. Et annet interessant funn var at teknisk profesjonell fagkunnskap ikke så ut til å påvirke den moralske vurderingsevne (Myyry \& Helkama 2002 i Myyry 2003). Et slikt funn bekrefter det Bergem tidligere hadde vist, at yrkesetisk rasjonalitet ikke fanges opp av en fagteknisk kompetanse, men må utvikles og trenes spesielt. Lignende indikasjoner fremkommer også i erfaringer fra amerikanske prosjekter der lærere har prøvd ut forskjellige arbeidsformer i ulike disipliner for å koble kritisk tenkning og evne til praktisk handling (Sullivan \& Rosin 2008). En studie på ingeniørstudenter viser at studenter som deltok $i$ et etikk-kurs der det blant annet ble jobbet med spørsmål om profesjonelt ansvar, konfidensialitet, interessekonflikter, forhold mellom ansatt og arbeidsgiver, lojalitet og varsling, uttrykte en bredere bevissthet om sitt yrkesetiske ansvar og omsorg for å handle til det beste for mennesker og miljø enn før de tok kurset (Loui 2005).

At utdanning påvirker studenters moralske orientering, indikeres også i et forskningsprosjekt gjennomført i 2002 og 2003, ledet av Jensen ved Pedagogisk forskningsinstitutt, Universitetet i Oslo. I dette prosjektet ble flere forhold rundt helse- og sosialfagstudenters normative og ekspressive kunnskap studert, blant annet hvilken rolle utdanning har i å kultivere et moralsk motiverende grunnlag for yrket. Forskerne som så på sykepleie-, sosialarbeider- og fysioterapiutdanning, fant at programmene i ulik grad stimulerte til moralsk engasjement, og at ingen av de respektive utdanningsmodellene alene var tilstrekkelige som orienteringsredskaper i yrker kjennetegnet ved tøffe arbeidsforhold og vanskelige valg.

Stilt overfor hverandre, kan likevel sykepleiens vektlegging på 'godhet', sosialarbeidernes 'saklighetsorientering' og fysioterapeutenes vektlegging på 'etisk sensibilitet' bidra til en produktiv dynamikk og kanskje også en mer gjennomtenkt politikk hva angår spørsmål knyttet til moral- og viljesdanning. (Jensen et al. 2005).

Denne studien avdekker også interessante funn når det gjelder senmoderne studenters orienteringer inn mot ulike yrkesliv. Blant annet indikerer resultatene at sykepleiestudenter evner å kombinere selvorientering og andreorientering blant annet ved å se omsorg for andre som meningsskapende også for ens egen utvikling (Jensen \& Tveit 2005). Slike funn er, etter min mening, fruktbare bidrag når vi diskuterer hvordan vi skal forstå og motivere for det normative profesjonelle kravet om å «tjene andre». 


\section{Oppsummerende drofting og implikasjoner for videre forskning}

Jeg har i denne artikkelen argumentert for nødvendigheten av å forstå det særegne ved yrkesetikk både som et politisk og et etisk anliggende. Jeg har videre pekt på høyere utdannings spesifikke ansvar for å utdanne profesjonelle aktører med en reflektert bevissthet om sitt yrkesetiske ansvar. Ut fra en antagelse om at vi trenger å lære av den empiriske forskningen som foreligger, har jeg presentert eksempler på hva tidligere forskning kan fortelle oss om læring av yrkesetikk. Og selv om denne empirisk forskningen er noe skrinn, og vi trenger mer forskning som fokuserer læringsprosesser både i studenters formelle utdanningsløp og i yrkesliv, konkluderer jeg med at forskningen viser at utdanning kan bidra til å utvikle en basis for yrkesetisk handlingskompetanse når det gjøres på en systematisk måte. Oppsummert peker det seg ut noen sentrale og kritiske forutsetninger og faktorer som vi må ta hensyn til:

- Både i utdanning som i arbeidskontekst må det jobbes med å utvikle en kollektiv reflektert forståelse for det særegne ved profesjoners yrkesetikk - både det politiske og det etiske mandat.

- Det politiske legitimerte samfunnsoppdraget som profesjonen er bærer av, må artikuleres og gjøres til gjenstand for moralsk vurdering i forhold til ens egen yrkespraksis.

- Sentrale profesjonsutøvere i utdanning og yrke må erkjenne sin betydning som rollemodeller - og ta konsekvensen av det.

- Det må utvikles språk for etisk vurdering av moralsk handling.

- Det må legges til rette for kommunikativ deliberasjon der de ulike aspekter ved yrkesetikk inngår.

- Det må legges til rette for læring gjennom autentiske historier og handling i praksis.

- Det må gis rom for kritisk vurdering av profesjoners verdiforankring og profesjonspraksis, men også av personlige holdninger og praksis.

- Vi må erkjenne at profesjonsutøvere ofte står i en kryssild mellom profesjonsdefinerte verdier og de normene som den lokale praksisen representerer, og se dette i forhold til hva som kan forstås som legitime fremforhandlede kompromisser.

I tillegg mener jeg at profesjonsetiker Ruyter har et viktig poeng når han argumenterer for at yrkesetiske dyder må få en høyere status i ulike fag- og profesjonsutdanninger. Et profesjonsspråk bør ha plass til begreper som godhet, barmhjertighet og solidaritet - selv i et intensivert markedsstyrt arbeidsliv. Den faglige komponenten og de moralske aspektene må veves sammen på en balansert måte ved at vi setter «dydene i midten», eller 
«moralen midt på treet», omtrent slik Ruyter formulerer det (Ruyter 2005: 112).

For senmoderne unge studenter og profesjonsutøvere, og kanskje for noen av oss andre, kan dette høres ut noe arkaisk, snerpete eller jomfruelig. Men Ruyters poeng er det motsatte. Slik han bruker begrepet, handler det om at profesjonsutøvere skal opptre faglig kompetent og etisk forsvarlig, men ikke fremstå som moralsk overlegne og ufeilbarlige. Det skaper ikke den tilliten til profesjoner og deres medlemmer som det moderne samfunnet må bygge på. Det er tilstrekkelig at for eksempel en klient, pasient eller elev blir møtt med lydhørhet, tålmodighet, omsorg og respekt. Og kanskje er det nettopp slike dyder vi jevnlig må børste støv av for å holde en høy bevissthet om det profesjonelle ansvaret. Gjennom aktivt å bruke etiske begreper og det politiske grunnlaget for våre profesjonelle handlinger kan vi kanskje hjelpe kommende profesjonsutøvere til å forstå sitt profesjonelle yrkesetiske mandat i lys av det samfunnsoppdraget som profesjonen er gitt, noe som kan øke bevisstheten om at yrkesetiske handlinger må forstås som et kollektivt og et personlig ansvar. Enkelte kan hevde at det er illusorisk å tro at det nytter $\mathrm{i}$ et markedsdominert arbeidsliv, men som forskningen antyder, kan systematisk arbeid med moralske og politiske spørsmål gi effekt. Vi trenger imidlertid mer forskning på relasjonen mellom det profesjonelle normative mandatet og hvordan den enkelte profesjonsutøvers oppfatter og lærer yrkesetikk, og hvordan dette praktiserer dette i et intensivt og konkurranseutsatt arbeidsliv.

\section{Noter}

1 Manuset er basert på prøveforelesning oppgitt tema 04.09.07 i forbindelse med disputas 05.09.07 for dr.polit.-graden ved Det utdanningsvitenskapelige fakultet, UiO.

2 Dette er mer inngående drøftet i Solbrekke (2008).

3 Poenget til Nygren og Fauske er interessant å se i lys av at lærerprofesjonen ved Utdanningsforbundet i forbindelse med Landsmøtet i 2006 igangsatte en profesjonaliseringsdebatt der de involverer hele organisasjonen for å formulere felles idealer som profesjonen kan samles om. Lastet ned 20. august fra http://profesjonsidealer.utdanningsforbundet.no/udf_kampanjTemplates/Page___39.aspx. Norsk Lærerlag forsøkte også i 1973, men lyktes ikke. Mange hevdet at læreres handlinger var tilstrekkelig regulert gjennom opplæringslov, læreplan og fag- og profesjonstradisjoner. Den individuelle friheten som er nødvendig i et yrke som fordrer et sterkt personlig engasjement for at elever skal få best mulig tilbud, burde derfor ikke snevres ytterligere inn. Om lærerne utvikler en felles yrkesetikk med flere konkrete føringer denne gangen, gjenstår å se. Uansett illustrerer slike debatter komplekse og viktige aspekter i spenningen mellom ytre reguleringer og det personlige moralske handlingsrom. Handal (1997) peker på noen lignende utfordringer i et innlegg om normativ etikk for universitetslærere. 
4 I denne artikkelen blir begrepene profesjonsetikk og yrkesetikk brukt om hverandre, og yrkesstatus og grad av autonomi blir ikke problematisert. Felles er imidlertid at i de yrkene som drøftes, gis de profesjonelle aktørene en viss grad av autonomi og står $i$ et relasjonelt ansvar til klient, profesjon, arbeidsgiver og samfunn. Jeg legger således til grunn den forståelsen som Christoffersen (2005) redegjør for, og ser bort fra det klassiske skillet mellom profesjoner og semiprofesjoner (jf. Torgersen 1972). Videre inkluderer en slik forståelse av profesjonsetikk, også grupper som lærere, som på tross av at de ikke har definerte yrkesetiske retningslinjer i kraft av sitt yrkes særegenhet og spesifikke kobling til undervisning av elever og studenter i høyeste grad har et spesifikt moralsk ansvar (Fenstermacher 2004; Bergem 1993; Colnerud 2006).

5 Denne undersøkelsen er interessant også med tanke på at lærere ikke har utviklet yrkesetiske kodekser, jf. note 2. Den illustrerer derfor tydelig at yrkestisk ansvar kan leses som innvevd aspekt i en profesjons kjernekunnskap.

6 Se oversikt over GOOD WORK-prosjektet. Lastet ned 27. august 2007 fra http://goodworkproject.org/docs/papers/GW\%20Overview\%201_06.pdf

7 Se div. på nettstedet http://verden.abcsok.no/index.html?q=Hans+Henrik+Knoop+ og+Good+work+project

8 Selv om jeg ikke går videre med en drøfting her, bemerkes det imidlertid at sykepleieutdanning har et godt utviklet vokabular for omsorgsdimensjonen i sin yrkesetiske læring (se f.eks. Solbrekke \& Jensen 2006).

\section{Litteratur}

Abbott, A. (1983) Professional ethics. The American Journal of Sociology, 88 (5), s. 855-885.

Abbott, A. (1988) The System of Professions: An Essay on the Division of Expert Labor. Chicago: University of Chicago Press.

Alford, F. (2001) Whistleblowers: Broken Lives and Organizational Power. Cornell University Press.

Elci, A. (2006) Professional ethics for professionals of computer \& info tech. Lastet ned 24. august 2007 fra http://cmpe.emu.edu.tr/aelci/Courses/D-598/ ProEthics_ICT_Elci.ppt

Bebeau, M. J. (1993) Designing an outcome-based ethics curriculum for professional education: Strategies and evidence of effectiveness. Journal of Moral Education, 22 (3), s. 313-326.

Bergem, T. (1993) Tjener - aldri herre. Om loererutdanning og yrkesetiske holdninger. Bergen: NLA-forlaget.

Bok, S. (1988) Whistleblowing and professional responsibilities. I Ethical issues in professional life, red. J. Callahan, s. 331-334. Oxford: Oxford University Press.

Castells, M. (2000) The Institutions of the New Economy. Summary of the address to the Delivering the Virtual Promise? Conference, London, 19th June 2000. Lastet ned 10. mai 2005 fra http://virtualsociety.sbs.ox.ac.uk/text/events/ castells.htm

Colnerud, G. (1995) Etikk och praktikk i läraryrket. En empirisk studie av lärares yrkesetiska konflikter i grundskolan. Doktoravhandling, Institutionen för Pedagogik och Psykologi, Linköpings Universitet, 1995 HLS Förlag.

Colnerud, G. (2006) Teacher ethics as a research problem: Syntheses achieved and new issues. Teachers and Teaching: Theory and Practice, 12 (3), s. 365-385. 
Christoffersen, S. Aa. (2005) Innledning. I Profesjonsetikk, red. S., Aa. Christoffersen, s. 9-16. Oslo: Universitetsforlaget.

Downie, R. S. \& Jodalen, H. (1997) 'I-thou' and 'doctor-patient'. A relationship examined. I Closeness. An ethics, red. H. Jodalen \& A. J. Vetlesen, s. 129-141. Oslo: Scandinavian University Press.

Durkheim, E. (1957/2001) Professional Ethics and Civic Morals. London: Routledge.

Evetts, J. (2006) Introduction: Trust and professionalism: Challenges and occupational changes. Current Sociology, 54 (4), s. 515-531.

Fenstermacher, G. D. (1986) Philosophy of research and teaching: Three aspects. I Handbook of research on teaching, red. M. C. Wittrock, s. 37-49. New York: Macmillian.

Fishman, W., Solomon, B., Greenspan, D. \& Gardner, H. (2004) Making Good: How Young People Cope with Moral Dilemmas at Work. Cambridge, Mass: Harvard University Press.

Freidson, E. (1970/1988) Profession of Medicine. A Study of the Sociology of Applied Knowledge. Chicago: The University of Chicago Press.

Freidson, E. (2001) Professionalism: The Third Logic. Cambridge: Polity Press.

Gardner, H., Csikszentmihalyi, M. \& Damon, W. (2001) Good Work - When Excellence and Ethics Meet. New York: Basic Books.

Grimen, H. (2005) Profesjonsetikken sitt grunnlag. Senter for profesjonsstudier, Høgskolen i Oslo. Lastet ned 29. august 2007 fra www.hio.no/content/view/ full/1756

Grimen, H. (2008) Profesjon og profesjonsmoral. I Profesjonsstudier, A. Molander \& L. I. Terum, s. 144-158. Oslo: Universitetsforlaget.

Gustavsson, B. (2004) Aristoteles: Förundrans och klokhetens tänkare. I Pedagogikkens mange ansikter, red. K. Steinsholt \& L. Løvlie, s. 36-50. Oslo: Universitetsforlaget.

Handal, G. (1997) Etikk i undervisning og veiledning. Innlegg på konferansen om Normativ etikk i universitetssamfunnet. Oslo, 10.-11. april 1997.

Hoshmand, L. T. (1998) Creativity and Moral Vision in Psychology. Narratives on Identity and Commitment in a Postmodern Age. London: Sage Publications.

Jensen, K., Fossestøl, B., Karseth, B. \& Tveit, B. (2005) Sluttrapport - Helse- og sosialfagstudentens normative og ekspressive Kunnskapsgrunnlag. Lastet ned 2. september 2007 fra www.hio.no/content/view/full/36 497

Jensen, K. \& Tveit, B. (2005) Youth culture - A source of energy and renewal for the field of nursing in Norway. I Dilemmas of Care in the Nordic Welfare State Continuity and Change, s. 161-175. England: Ashgate.

Karseth, B. \& Solbrekke, T. D. (2006) Characteristics of graduate professional education: Expectations and experiences in psychology and law. London review of Education, 4 (2), s. 149-167.

Kohlberg, L. (1984) The Psychology of Moral Development: The Nature and Validity of Moral Stages. San Fransisco: Harper \& Row.

Komulainen, K. J. (2006) Neoliberal educational policy. A case study of Finnish textbooks of entrepreneurial education. Nordisk Pedagogik, 26 (3), s. 212-228.

Kryssildprosjektet (2006) Lastet ned 2. september 2006 fra http://web.hil.no/kryssildprosjektet/

Levinas, E. (1988) Etik och oündelighet. Samtal med Philippe Nemo. Stockholm/ Lund: Symposium. 
Loui, M. C. (2005) Ethics and the Development of Professional Identities of Engineering Students. Lastet ned 24. juni 2008 fra https://netfiles.uiuc.edu/loui/www/ jeeOct05.pdf

Myyry, L. (2003) Components of Morality. A Professional Ethics Perspective on Moral Motivation, Moral Sensitivity, Moral Reasoning and Related Constructs Among University Students. Doktoravhandling, Faculty of Social Sciences, Helsinki Universitet.

Nafstad, H. E. (2005) Assumptions and values in production of knowledge: Towards an area ethics of psychology and the social sciences. I Values in Higher Education, red. S. Robinson \& C. Katulishi, s. 150-158. Cardiff, Wales: Aureus Publishing Limited \& The University of Leeds.

Nortvedt, P. (2005). Profesjonsetikkens grunnlag. Senter for profesjonsstudier, Høgskolen i Oslo. Lastet ned 29. august fra www.hio.no/content/view/full/34 782

Nortvedt, P. (2006) Følelser og fornuft - etisk teoridebatt med relevans for helsefagene. I Etikk for helsefagene, Å. Slettebø \& P. Nortvedt, s. 35-48. Oslo: Gyldendal Akademisk.

Nygren P. \& Fauske H. (2004) Ideologisk beredskap - Om etikk og verdier i helse- og sosialfag. Oslo: Gyldendal Akademisk.

Parsons, T. (1951) The Social System. New York: The Free Press.

Parsons, T. (1968) Professions. International Encyclopedia of the Social Sciences, 12, s. 536-547. New York: The Free Press and Macmillian.

Ruyter, K. W. (2005) Dyder er ikke tilleggsgoder - en utfordring for profesjonsutdanningene. I Profesjonsetikk, S. Aa Christoffersen, s. 105-138. Oslo: Universitetsforlaget.

Schön, D. A. (1982) The Reflectice Practitioner. How Professionals Think in Action. New York: Basic Books.

Sennett, R. (1998) The Corrosion of Character. The Personal Consequences of Work in the New Capitalism. New York: W.E Norton \& Company

Scott, P. (2005) The university and civic values. I Values in Higher Education, red. S. Robinson \& C. Katulushi (red.), s. 8-23. Cardiff, Wales: Aureus \& The University of Leeds.

Slettebø, Å. (2006) Etikk og jus. I Etikk for helsefagene, red. Å. Slettebø \& P. Nortvedt, s. 17-33. Oslo: Gyldendal Akademisk.

Slettebø, Å. \& Nortvedt, P. (red.) (2006) Etikk for helsefagene. Oslo: Gyldendal Akademisk.

Sockett, H. (1993) The Moral Base for Teacher Professionalism. New York: Teachers College Press.

Solbrekke, T. D. \& Jensen, K. (2006) Learning the moral order of professions; the contrasting approaches of nursing and clinical psychology. Learning in Health and Social Care, 5 (4), s. 181-193.

Solbrekke, T. D. (2007a) Understanding Conceptions of Professional Responsibility. Doktoravhandling. Series of dissertations submitted to Det utdanningsvitenskapelige fakultet, Universitetet i Oslo, 88, s. 1-119.

Solbrekke, T. D. (2008) Professional responsibility as legitimate compromises from communities of education to communities of work. Studies in Higher Education, 33 (4), s. 485-500.

Solbrekke, T. D. (2008) Den normative dimensjon i høyere utdanning. UNIPED, 31 (2), s. 5-18. 
Sullivan,W. M. (2005) Work and Integrity. The Crisis and Promise of Professionalism in America. San Francisco, CA: Jossey-Bass.

Sullivan, W.M. \& Rosin, M. S. (red.) (2008) A New Agenda for Higher Education. Shaping a Life of the Mind for Practice. San Francisco, CA: Jossey-Bass.

Taylor, C. (1989) Sources of the Self: The Making of Modern Identity. Cambridge, Mass.: Cambridge University Press.

Tirri, K. (2003a) Professional morality of academic leaders. Paper presentert på SIG, invitert symposium, Professions and its Morality. Earli Conference in Padova, Italia 26.-30. august 2003.

Tirri, K. (2003b) The teacher's integrity. I Teaching in Moral and Democratic Education, red. W. Veugelers \& F. K. Oser, s. 65-84. Bern: Peter Lang.

Tjora, A. (red.) (2008) Den moderne pasienten. Oslo: Gyldendal Akademisk.

Torgersen, U. (1972) Profesjonssosiologi. Oslo: Universitetsforlaget.

Tranøy, K. E. (1998) Det åpne sinn. Moral og etikk mot et nytt årtusen. Oslo: Universitetsforlaget.

Ylijoki, O.-H. (2000) Disciplinary cultures and the morals order of studying - A case-study of four Finnish university departments. Higher Education, 39, s. 339-362. 